\title{
PENGARUH KEPATUHAN WAJIB PAJAK DAN PENAGIHAN PAJAK TERHADAP PENERIMAAN PPH PASAL 25/29 WAJIB PAJAK BADAN PADA KPP PRATAMA BATANG
}

\author{
Oleh : \\ Imas Septiyani Hanifah \\ R. Ery Wibowo Agung S \\ Program Studi Akuntansi \\ Fakultas Ekonomi \\ Universitas Muhammadiyah Semarang
}

\begin{abstract}
One of the things that influence the most of the acceptance of income tax article 25/29corporate taxpayers is the level of tax compliance, especially in BatangPratama Tax Office. The large amount of income tax revenue of article 25/29 corporate taxpayers nothing to do with the level of tax compliance, ie whether or not the obedient corporate taxpayers in paying taxes.

The purpose of this study was to determine the effect of tax compliance and tax collection on income tax receipts article 25/29 corporate taxpayers in the BatangPratamaTax Office period 2008-2012. The survey was conducted at the BatangPratamaTax Office and units of analysis are secondary data from reports of receipts of income tax article 25/29 corporate taxpayers the period 2008-2012. Regression models were used in compliance with the classical assumption test. The data analysis technique used is the technique of multiple linear regression analysis using SPSS version 16.0

The results showed that in the period of 5 (five) years ie 2008 to 2012, the amount of income tax revenue of article 25/29 corporate taxpayers in the BatangPratama Tax Office continued to increase from year to year, tax compliance and collection tax simultaneously and partially significant effect on income tax receipts article 25/29 taxpayers on BatangPratamaTax Office period 2008-2012.
\end{abstract}

Keywords: Taxpayer Compliance, Tax Billing, Tax Receipts Article 25/29, the Taxpayer. 


\section{PENDAHULUAN}

Pajak merupakan aspek yang penting dalam proses pembangunan suatu negara khususnya di Indonesia, karena pembangunan bertujuan untuk mewujudkan serta meningkatkan kesejahteraan suatu Negara.Awal tahun 1984 sistem perpajakan Indonesia mengalami reformasi yang sering disebut dengan tax reform, yaitu perubahan dari official assessment system menjadi self assessment system. Perbedaan antara dua system ini, yakni dalam official assessment system tanggung jawab pemungutan terletak sepenuhnya pada pemerintah, sedangkan dalam self assessment system wajib pajak diberi kepercayaan penuh untuk menghitung, memperhitungkan, membayar atau menyetor, dan melaporkan besarnya pajakyang terutang sesuai dengan jangka waktu yang telah ditentukan dalam peraturan perundang-undangan perpajakan. Konsekuensi dari perubahan ini adalah Direktorat Jenderal Pajak (DJP) berkewajiban untuk melakukan pelayanan, pengawasan, pembinaan, dan penerapan sanksi pajak. Usaha dilakukan fiskus untuk efektivitas jalannya self assessment system dan meningkatkan penerimaan pajak, antara lain dengan melakukan ekstensifikasi dan intensifikasi penerimaan pajak.

Kepatuhan wajib pajak, baik orang pribadi maupun badan, yang terdaftar di Kantor Pelayanan Pajak dan telah melakukan kewajiban perpajakannya, yaitu dengan melunasi dan melaporkan SPT masa dan tahunannya tepat waktu (Oktivani, 2007). Kepatuhan wajib pajak merupakan syarat agar penerimaan pajak negara meningkat. Dalam Fika Agusti (2008) disimpulkan bahwa terdapat pengaruh positif antara tingkat kepatuhan wajib pajak terhadap peningkatan penerimaan pajak pada Kantor Pelayanan Pajak Pratama Jakarta Grogol Petamburan.Menurut Junaidi Eko Widodo (2004), tingkat kepatuhan Wajib Pajak biasanya diukur dengan tingkat ketidakpatuhan yang pada umumnya diukur dengan menggunakan tax gap yaitu perbedaan 
antara pajak yang diterima berdasarkan pelaporan wajib pajak secara sukarela dengan jumlah yang ditentukan oleh pemeriksa pajak. Jadi, semakin patuh wajib pajak badan melaporkan dan melunasi kewajiban perpajakannya maka penerimaan pajak pada KPP akan semakin meningkat.

Salah satu fungsi dari penerbitan STP tersebut adalah sebagai dasar hukum bagi Direktorat Jenderal Pajak untuk menagih jumlah pajak yang tidak dibayar oleh wajibpajak. Dalam pasal 18 ayat 1 Undang-undang No 9 tahun 1994 yang diubah dengan Undang-undang terakhir yaitu Undang-undang tentang Ketentuan Umum dan Tata Cara Perpajakan No 16 tahun 2000 bahwa Surat Tagihan Pajak, Surat Ketetapan Pajak Kurang Bayar, Surat Ketetapan Pajak Kurang Bayar Tambahan dan Surat Keputusan Pembetulan, Surat Keputusan Keberatan Putusan Banding yang menyebabkan jumlah pajak yang harus dibayar bertambah merupakan dasar penagihan pajak. Hal ini pula yang dijadikan sebagai dasar perhitungan jumlah tunggakan pajak yang tercatat di Kantor Pelayanan Pajak.

Surat Tagihan pajak merupakan surat pertama yang dikeluarkan jika wajib pajak tidak atau kurang bayar pajak, harus membayar denda, belum menjadi pengusaha kena pajak tetapi telah memungut pajak PPN, atau telah dikukuhkan, membayar dan melaporkan PPN tetapi tidak benar (Ilyas dan Burton 2008). Surat Tagihan Pajak diterbitkan dengan tujuan untuk menjaga penerimaan negara yang seharusnya diterima dari sektor pajak. Surat tagihan pajak diharapkan dapat meningkatkan kepatuhan wajib pajak dalam membayar pajak..Menurut Ginting (2006) wajib pajak yang terutang pajak, $95 \%$ mau membayar pajak setelah diberikan surat ketetapan pajak.

Penerimaan dan peningkatan peranan pajak dalam pembangunan Indonesia menjadi target dan tugas Direktorat Jenderal Pajak (DJP) sebagai lembaga otoritas pajak. Dalam KPP Pratama, diperkenalkan konsep pemberian pelayanan satu atap, artinya KPP Pratama memberikan pelayanan 
atas semua jenis pajak yang diadministrasikan oleh pemerintah pusat, yaitu PPh, PPN, PBB serta jenis pajak lainnya termasuk penagihan pajak.

\section{TUJUAN PENELITIAN}

\section{Berdasarkan permasalahan penelitian yang telah diuraikan sebelumnya, maka penelitian ini memiliki tujuan sebagai berikut: \\ 1. Untuk memperoleh bukti empiris pengaruh kepatuhan wajib pajak terhadap penerimaan $\mathrm{PPh}$ pasal 25/29 wajib pajak badan pada Kantor Pelayanan Pajak Pratama Batang secara parsial.}

2. Untuk memperoleh bukti empiris pengaruh penagihan pajak terhadap penerimaan $\mathrm{PPh}$ pasal 25/29 wajib pajak badan pada Kantor Pelayanan Pajak Pratama Batang secara parsial.

3. Untuk memperoleh bukti empiris pengaruh kepatuhan wajib pajak dan penagihan pajak terhadap penerimaan $\mathrm{PPh}$ pasal 25/29 wajib pajak badan pada Kantor
Pelayanan Pajak Pratama Batang secara simultan.

\section{TINJAUAN PUSTAKA}

Pajak merupakan salah satu sumber pembiayaan bagi negara dalam menjalankan roda pemerintahan. Pajak mempunyai bagian penting dalam pembangunan diseluruh aspek kehidupan di negara ini. Tanpa pajak, pembangunan tidak akan berjalan lancar karena besarnya pembiayaan yang diperlukan tidak bisa tertutupi hanya dengan pinjaman dan bantuan dari luar negeri.

Menurut Undang-undangNo 28 tahun 2007 tentang Ketentuan Umum dan Tata Cara Perpajakan (KUP) pasal 1 ayat (1) :

"Pajak adalah kontribusi wajib pajak kepada negara yang terutang oleh orang pribadi atau badan yang bersifat memaksa berdasarkan Undangundang, dengan tidak mendapatkan imbalan secara langsung dan digunakan untuk keperluan negara bagi sebesar-besarnya kemakmuran rakyat." 
Banyak para ahli memberikan batasan tentang pajak, diantaranya pengertian pajak yang dikemukakan oleh Brotodiharjo (2007) Ia mengemukakan bahwa pajak adalah peralihan kekayaan dari pihak rakyat kepada kas negara untuk membiayai pengeluaran rutin dan surplusnya digunakan untuk public serving yang merupakan sumber utama untuk membiayai public investment.

Dalam rangka penerimaan pajak perlu diketahui teori-teori yang melatarbelakangi dilakukannya pemungutan pajak, sebagaimana diungkapkan Rimsky dalam Suharno (2003), yaitu:

1. Teori Asuransi

2. Teori Kepentingan

3. Teori Bakti

4. Teori Daya Pikul

5. Teori Daya Beli

Menurut Chaizi Nasucha (2004) Kepatuhan Wajib Pajak dapat didefinisikan diri kepatuhan Wajib pajak dalam mendaftarkan diri, kepatuhan wajib pajak untuk menyetor kembali Surat Pemberitahuan (SPT), kepatuhan dalam penghitungan dan pembayaran pajak terutang dan kepatuhan dalam pembayaran tunggakan.

Pelaksanaan penagihan pajak yang tegas, konsisten dan konsekuen diharapkan akan dapat membawa pengaruh positif terhadap kepatuhan Wajib Pajak dalam membayarkan hutang pajaknya. Hal ini merupakan posisi strategis dalam meningkatkan penerimaan negara dari sektor pajak sehingga tindakan penagihan pajak tersebut dapat menyelamatkan penerimaan pajak yang tertunda.Dasar hukum melakukan tindakan penagihan pajak adalah Undang-undang No. 19 tahun 1997 tentang Penagihan Pajak dengan Surat Paksa. Undang-undang ini mulai berlaku tanggal 23 Mei 1997. Undang-undang ini kemudian diubah dengan Undang-undang No. 19 tahun 2000 yang mulai berlaku pada tanggal 1 Januari 2001.

Undang-undang Pajak penghasilan (PPh) mengatur subjek pajak, objek pajak serta cara menghitung dan cara melunasi pajak yang terutang. Undang-undang Pajak Penghasilan (PPh) juga lebih 
memberikan fasilitas kemudahan dan keringanan bagi Wajib Pajak dalam melaksanakan kewajiban perpajakan. Rusli (2003), Pajak Penghasilan adalah pajak yang dikenakan terhadap subjek pajak atas penghasilan yang diterima atau diperolehnya dalam tahun pajak.

\section{Perumusan Hipotesis}

Penelitian ini akan menerangkan bagaimana Pengaruh Kepatuhan Wajib Pajak dan Penagihan Pajak terhadap Penerimaan PPh pasal 25/29 Wajib Pajak pada KPP Pratama Batang. Kerangka penelitian dapat digambarkan sebagai berikut :

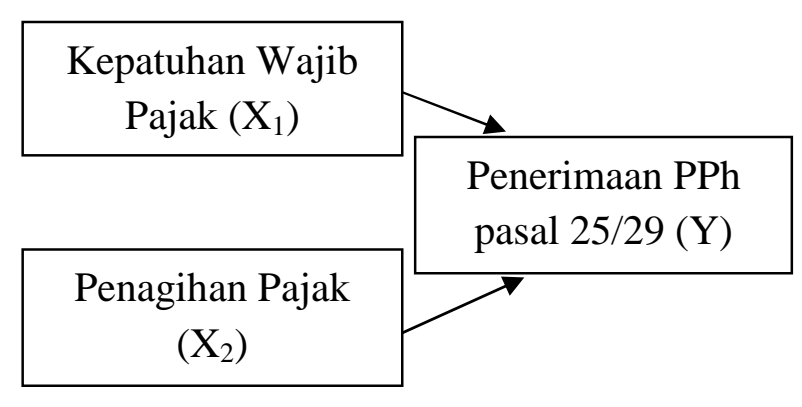

Adapun hipotesis penelitian ini adalah sebagai berikut :

$$
\begin{gathered}
\mathrm{H}_{1} \text { : } \begin{array}{c}
\text { Kepatuhan } \\
\text { berpengaruh }
\end{array} \text { positif } \begin{array}{r}
\text { Pajak } \\
\text { Penerimaan }
\end{array} \text { PPh Pasal } 25 / 29
\end{gathered}
$$

Wajib Pajak Badan pada Kantor Pelayanan Pajak Pratama Batang secara Parsial.

$\mathrm{H}_{2}$ : Penagihan Pajak berpengaruh positif terhadap Penerimaan PPh Pasal 25/29 Wajib Pajak Badan pada Kantor Pelayanan Pajak Pratama Batang secara Parsial.

$\mathrm{H}_{3}$ : Kepatuhan Wajib Pajak dan Penagihan Pajak berpengaruh secara simultan terhadap Penerimaan PPh Pasal 25/29 Wajib Pajak Badan pada Kantor Pelayanan Pajak Pratama Batang.

\section{PENELITIAN}

Variabel penelitian adalah objek penelitian yang bervariasi (Suharsimi Arikunto, 2006). Variable merupakan besaran yang memiliki variasi nilai. Penelitian ini menggunakan 2 variabel yaitu variable bebas (Independent Variable) dan variable terikat ( Dependent Variable). Menurut Arikunto (2006), sampel merupakan sebagian atau wakil dari populasi yang akan diteliti. Penentuan sampel yang digunakan dalam penelitian ini adalah proportional sampling methodatau 
pemilihan sampel proporsional, yaitu metode penentuan sampel yang memberikan peluang yang sama bagi setiap anggota populasi untuk dipilih menjadi anggota sampel (Sugiyono, 2004). Teknik sampel ini dipilih karena anggota populasinya dianggap homogen, yaitu wajib pajak badan pada KPP Pratama Batang.

Jenis data penelitian merupakan faktor penting yang menjadi pertimbangan dalam penentuan metode pengumpulan data. Jenis dan sumber data yang digunakan dalam penelitian ini adalah :

1. Data primer merupakan sumber data penelitian yang diperoleh secara langsung dari sumber asli berupa wawancara kepada pihak atau pegawai KPP Pratama Batang khususnya pegawai bagian penagihan pajak dan pelayanan pajak.

2. Data sekunder merupakan data yang telah diolah lebih lanjut menjadi bentuk-bentuk seperti tabel, gambar, dan lain-lain. Selain itu terdapat data yang diperoleh melalui data kepustakaan dan sumber tertulis lainnya berupa literatur-literatur dan peraturan yang berhubungan dengan pokok bahasan yang diteliti.

Metode pengumpulan data pada penelitian ini adalah dengan menggunakan wawancara, dokumentasi dan observasi dengan cara menyalin dan mengolah dokumen atau catatan tertulis yang ada seperti penerimaan pajak penghasilan pasal $25 / 29$, kepatuhan wajib pajak serta penagihan pajak, yaitu pencatatan jumlah SKPKB, SKPKBT, dan surat pembetulan, surat keputusan keberatan banding yang diterbitkan Kantor Pelayanan Pajak Pratama Batang.

\section{Metode Analisis}

Analisis data yang digunakan untuk menganalisis data adalah metode deskriptif kualitatif. Metode deskriptif kualitatif merupakan pencatatan data yang disertai dengan kalimat, kata atau gambar untuk memberikan gambaran dari masalah yang diteliti.Untuk mengetahui ada atau tidaknya pengaruh kepatuhan wajib pajak dan penagihan pajak terhadap penerimaan 
PPh pasal 25/29 wajib pajak badan pada KPP Pratama Batang digunakan model Regresi Linier Berganda dan proses datanya menggunakan program Komputer SPSS 16.0. Model tersebut dapat dinyatakan dalam bentuk umum persamaan regresi linear berganda :

$$
\mathrm{Y}=\alpha+\mathrm{b}_{1} \mathrm{X}_{1}+\mathrm{b}_{2} \mathrm{X}_{2}
$$

$+\varepsilon$

Uji hipotesis yang digunakan adalah Uji t (pengujian parsial) dan Uji $\mathrm{f}$ (pengujian simultan) dengan dasar pengambilan keputusan adalah :
a. Jika $\mathrm{t}_{\mathrm{h}}<\mathrm{t}_{\mathrm{t}_{\mathrm{i}}}$, maka $\mathrm{H}_{\mathrm{b}}$ diterima
b. Jika $\mathrm{t}_{\mathrm{h}} \quad>\mathrm{t}_{\mathrm{t}_{\mathrm{i}}} \quad$, maka $\mathrm{H}_{0}$ ditolak

Berdasarkan signifikansi dasar pengambilan keputusannya adalah :
a. Jika signifikansi $>0,05$, maka $\mathrm{H}_{0}$ diterima
b. Jika signifikansi $<0,05$, maka $\mathrm{H}_{\square}$ ditolak

\section{HASIL PENELITIAN}

Hasil Uji Statistik Deskriptif

\begin{tabular}{|l|r|r|r|r|r|}
\hline & \multicolumn{1}{c|}{ Descriptive Statistics } \\
\hline & N & Minimum & Maximum & \multicolumn{1}{c|}{ Mean } & \multicolumn{1}{c|}{$\begin{array}{c}\text { Std. } \\
\text { Deviation }\end{array}$} \\
\hline Kepatuhan Wajib Paj; & 60 & 1657,00 & 5290,00 & 3496,583 & 1021,028 \\
Penagihan Pajak & 60 & 2,00 & 680,00 & 211,1500 & 162,97144 \\
Penerimaan PPH25/2 & 60 & $2 \mathrm{E}+008$ & $1 \mathrm{E}+009$ & $6 \mathrm{E}+008$ & $2,5 \mathrm{E}+008$ \\
Valid N (listwise) & 60 & & & & \\
\hline
\end{tabular}

bahwa rata-rata penerimaan $\mathrm{PPh}$

pasal 25/29 wajib pajak badan (dengan data 60 bulan) adalah Rp.6 x 109, dengan standar deviasi Rp. 2.500.000.000,-. Rata - rata kepatuhan wajib pajak badan yang aktif (dengan data 60 bulan) adalah 34,96 persen, dengan standar deviasi 10,21 persen. Rata-rata penagihan pajak wajib pajak badan (dengan data 60 bulan) adalah 21,11 persen dengan standar deviasi 16,29 persen.

\section{Tabel Durbin Watson Statistik}

\begin{tabular}{|c|c|c|c|c|c|}
\hline \multicolumn{6}{|c|}{ Model Summary ${ }^{b}$} \\
\hline Model & $R$ & R Square & $\begin{array}{l}\text { Adjusted } \\
\text { R S Square }\end{array}$ & $\begin{array}{l}\text { Std. Error of } \\
\text { the Estimate }\end{array}$ & $\begin{array}{l}\text { Durbin- } \\
\text { Watson } \\
\end{array}$ \\
\hline
\end{tabular}

b. Dependent Variable: Penerimaan PPH25/29

Durbin-watson

statistic

menunjukkan bahwa nilai durbinWatson sebesar 0,947, nilai ini akan dibandingkan dengan nilai tabel dengan menggunakan derajat kepercayaan 5\% jumlah sampel 60 dan jumlah variabel 3, maka ditabel Durbin-Watson akan didapatkan Durbin-Watson0,947 terletak antara 
batas -2 sampai 2.Berarti tidak terjadi autokorelasi, sehingga model regresi layak dipakai.

\section{Perhitungan Regresi Linear Berganda}

Coefficięnts koefisien regresi $\mathrm{X}_{1}$ (Kepatuhan Wajib Pajak) sebesar 0.368 menyatakan bahwa setiap penambahan $($ karena +$) 1$ maka kepatuhan wajib pajak akan meningkatkan penerimaan $\mathrm{PPh}$ sebesar

\begin{tabular}{|c|c|c|c|c|c|c|c|c|}
\hline \multirow{2}{*}{\multicolumn{2}{|c|}{ Mode }} & \multicolumn{2}{|c|}{$\begin{array}{c}\text { Unstandardize } \\
\text { Coefficients }\end{array}$} & \multirow{2}{*}{$\begin{array}{c}\begin{array}{r}\text { Standardiz } \\
\text { Coefficier }\end{array} \\
\text { Beta }\end{array}$} & \multirow[b]{2}{*}{$\mathrm{t}$} & \multirow[b]{2}{*}{ Sig. } & \multicolumn{2}{|c|}{ Collinearity S } \\
\hline & & $B$ & Std. Err & & & & Toleran & VIF \\
\hline \multirow[t]{3}{*}{1} & (Constant) & $3 E+0 d$ & $1 \mathrm{E}+00$ & & 2,53 & ,014 & & \\
\hline & Kepatuhan Wajil & 88660, & 29751,3 & ,368 & 2,980 & ,004 & ,994 & 1,000 \\
\hline & Penagihan Pajak & 91264,8 & 122214 & ,421 & 3,17 &, 003 & 994 & $1,00 \mathrm{~d}$ \\
\hline
\end{tabular}

a.Dependent Variable: Penerimaan PPH25/29

Dari tabel di atas dapat dirumuskan persamaan regresi berganda :

$$
\begin{gathered}
\mathrm{Y}=u+b_{1} X_{1}+b_{2} X_{2}+\varepsilon \\
\mathrm{Y}=3.000 .000 .000+0.368 \mathrm{X}_{1} \\
+0.421 \mathrm{X}_{2}+\varepsilon
\end{gathered}
$$

Keterangan : Y adalah Penerimaan $\mathrm{PPh}$ 25/29, $\mathrm{X}_{1}$ adalah Kepatuhan Wajib Pajak, $\mathrm{X}_{2}$ adalah Penagihan Pajak. Dari sini dapat diterangkan bahwa Konstanta Penerimaan PPh sebesar Rp.

$$
\text { 3,000.000.000,- menyatakan }
$$

bahwa jika tidak ada Kepatuhan Wajib Pajak dan Penagihan Pajak maka penerimaan $\mathrm{PPh}$ adalah $\mathrm{Rp}$. $3,000.000 .000,-$

Variabel penerimaan $\mathrm{PPh}$ memiliki pengaruh yang kuat positif. Hal tersebut dibuktikan dengan penelitian diperoleh hasil bahwa
Koefisien regresi $\mathrm{X}_{2}$ (Penagihan Pajak) sebesar 0.421 menyatakan bahwa setiap penambahan $($ karena +$) 1$ penagihan pajak akan meningkatkan penerimaan PPh sebesar 0.421.

Berdasarkan hasil perhitungan dengan menggunakan program SPSS variabel kepatuhan Wajib pajak diperoleh $\mathrm{t}$ hitung $=2,980$, sedangkan $\mathrm{t}$ tabel dengan $\alpha=0,05$ dan d.f $=n-2$,

\begin{tabular}{|c|c|c|c|c|c|c|}
\hline \multicolumn{7}{|c|}{ ANOVA ${ }^{b}$} \\
\hline Model & & $\begin{array}{r}\text { Sum of } \\
\text { Squares }\end{array}$ & $d f$ & Mean Square & $\mathrm{F}$ & Sig. \\
\hline \multirow{3}{*}{1} & Regression & $5 \mathrm{E}+017$ & 2 & $2,448 \mathrm{E}+017$ & 4,526 &, $015^{2}$ \\
\hline & Residual & $3 E+018$ & 57 & $5,410 \mathrm{E}+016$ & & \\
\hline & Total & $4 \mathrm{E}+018$ & 59 & & & \\
\hline
\end{tabular}
maka diperoleh $\mathrm{t}$ tabel $=2,000$ (pakai dua sisi).

\section{Hasil Uji F}

Berdasarkan hasil perhitungan dengan menggunakan program SPSS di peroleh $\mathrm{F}$ hitung $=4,526$. 
Sedangkan $\mathrm{F}$ tabel dengan $\alpha=0,05$

dan d.f $=(\mathrm{k}-1 ; \mathrm{n}-\mathrm{k}-1)=(1 ; 59$

) maka diperoleh $\mathrm{F}$ tabel $=2,001$.

\section{KESIMPULAN}

1. Kepatuhan Wajib Pajak secara parsial berpengaruh signifikan terhadap penerimaan $\mathrm{PPh}$ pasal 25/29 Wajib Pajak badan pada Kantor Pelayanan Pajak Pratama Batang periode 20082012. Adapun besarnya pengaruh variabel kepatuhan wajib pajak ditunjukkan dengan t hitung sebesar 2,980. Sedangkan besarnya pengaruh penagihan pajak ditunjukkan dengan t hitung sebesar 3,174. Sehingga $t$ hitung penagihan pajak $(3,174)>t$ hitung kepatuhan wajib pajak $(2,980)$.

2. Kepatuhan Wajib Pajak danpenagihan pajak secara simultan berpengaruh signifikan terhadap penerimaan PPh pasal 25/29 Wajib Pajak badan pada Kantor Pelayanan Pajak Pratama Batang periode 2008-2012. Adapun besarnya pengaruh variabel bebas terhadap variabel terikat adalah sebesar 37 persen sedangkan sisanya sebesar 63 persen dipengaruhi faktor lain yang tidak dijelaskan dalam model.

\section{DAFTAR PUSTAKA}

Agusti, Asri Fika. 2008. "Pengaruh Tingkat Kepatuhan Wajib Pajak Badan Terhadap Peningkatan Penerimaan Pajak Yang Dimoderasi Oleh Pemeriksaan Pajak Pada KPP Pratama”. Makalah SNA XII.

Arikunto, Suharsimi. 2006. Prosedur Penelitian. Jakarta: PT. Rineka Cipta.

Brotodihardjo, S. 2003. Pengantar Ilmu Hukum Pajak. Edisi Keempat. Bandung: PT.Refika Aditama, 2-4.

Chaizi, Nasucha. 2004. Reformasi Administrasi Publik : Teori dan Praktik. Jakarta: Gramedia.

Ghozali, Imam. 2011. Aplikasi Analisis Multivariate dengan Program SPSS. Semarang : Badan Penerbit Universitas Diponegoro.

Ginting, Riskon. 2008. Pengaruh Pemberian Surat Penagihan 
Terhadap

PembayaranTunggakan

Pajak Penghasilan di Tiga Kantor Pelayanan Pajak. Jurnal Ekonomi danBisnis. Volume 5 No. 1

Ilyas, Wirawan B. Richard Burton. 2008. Hukum Pajak. Jakarta : Salemba Empat

Oktivani, Debby. 2007. "Pengaruh Kepatuhan Wajib Pajak dan Jumlah Pemeriksaan terhadap Penerimaan Pajak Penghasilan di Kantor Pelayanan Pajak Madiun”.SkripsiSarjana Jurusan Akuntansi Fakultas Ekonomi Universitas Kristen Petra, Surabaya.

Sugiyono. 2004. Analisis Data untuk Riset Manajemen dan Bisnis (Metode Penelitian Bisnis). Bandung : CV Alfabeta.

Suharno. 2003. Pengelolaan Pajak dalam Era Otonomi Daerah. Bandung : Alfabet.
Undang-Undang No. 16 Tahun 2000 tentang Ketentuan Umum dan Tata Cara Perpajakan.

Undang-undang nomor 28 tahun 2007 Tentang Ketentuan Umum dan Tata Cara Perpajakan.

Undang-Undang No.19 Tahun 2000 Tentang " Penagihan Pajak Dengan Surat Paksa"

Widodo, Junaedi Eko. 2004. "Memanfaatkan Data Pemeriksaan untuk Menganalisis Kepatuhan Wajib Pajak." dalam Robert Pakpahan dan Toyomu Yuasa, peny., Menuju Sistem dan Administrasi Perpajakan Berkelas Dunia: Studi Perpajakan di Indonesia dengan Inspirasi Pengalaman Jepang, Jakarta: Penerbit Kharisma. 